\title{
G-Protein Coupled Receptor Family C Group 5 Member C
}

National Cancer Institute

\section{Source}

National Cancer Institute. G-Protein Coupled Receptor Family C Group 5 Member C. NCI Thesaurus. Code C26229.

G-protein coupled receptor family C group 5 member C (441 aa, $48 \mathrm{kDa}$ ) is encoded by the human GPRC5C gene. This protein may play a role in retinoic acid-mediated signaling. 